\title{
The birth of a new industry: entry by start-ups and the drivers of fir growth The case of encryption software
}

\author{
Marco S. Giarratana* \\ Department of Business Administration, Universidad Carlos III de Madrid, Calle Madrid 126, 28903 Getafe, Madrid, Spain
}

Received 1 April 2003; received in revised form 1 November 2003; accepted 7 January 2004

Available online 14 March 2004

\begin{abstract}
The paper analyses the birth of the encryption software industry (ESI), a new niche in the software industry. Using a Chandlerian perspective, this work reports the main facts about fir entry and growth, with a particular focus on start-up strategies and actions.

Since scale economies do not play a major role in ESI, the paper investigates the different sources of fir competitive advantages.

This work shows that innovation and product differentiation, along with investments in co-specialised assets, are variables strongly correlated to young fir probability to survive and grow. In doing so, we have collected highly detailed information on product introduction, US patents granted, worldwide alliances and biographical data of fir founders.
\end{abstract} (C) 2004 Elsevier B.V. All rights reserved.

JEL classificatio M13; L86; O32

Keywords Entry; Entrepreneurship; Innovation; Software

\section{Introduction ${ }^{1}$}

How do new industries emerge? What are the main drivers of fir entry and growth? Where do the actual market leaders come from?

These "Big-Bang" questions are usually unanswered in the literature, mainly because it is daring to collect reliable data of earlier industry stages. Even if Alfred Chandler's works have proved that these issues are fundamental, far too few are the studies that

\footnotetext{
* Tel.: +34-919249608; fax: +34-916249607.

E-mail address marco.giarratana@uc3m.es (M.S. Giarratana).

1 The usual disclaims apply.
}

investigate the birth of industries. Moreover, the richness of information that can be collected in the firs stages of an industry goes well beyond conventional wisdom of management and industrial studies.

Opening the black-box of the initial industry history is the main goal of this paper, which describes with massive empirical evidence all the main features and actors of a new market from its very beginnings. This will allow us to draw original insights on competition forces and strategic directions of a specifi industry in which innovation, entrepreneurship and fir growth strategies are strictly interrelated. Moreover, what distinguishes this study from a classical Chandlerian industry study is the focus on a highly 
skill-based industry. In this sense, exploitation of scale economies does not play a major role and firm have to fin different sources of competitive advantages.

Particularly, this paper studies the birth and development of the encryption software industry (ESI), a market niche in the software industry. In ESI new start-ups were able to dominate the market, exploiting firs business opportunities and previous technological breakthroughs of large incumbents. As a consequence, we will see that the history of this industry can mainly be described by small start-ups dynamics.

In so doing, we follow a common trend in the standard literature on small businesses (Churchill and Lewis, 1983; Kazanjian, 1988; Mitra and Pingali, 1999) and separate our analysis in two main sections. First we study the entry process and then we follow the leading start-ups along their path of growth. In fact, several contributions on this topic (Olson, 1987; Hanks and Chandler, 1994; Zacharakis et al., 1999) have long stressed that the capabilities that allow firm to survive in the firs place are completely different from those yielding fir growth. This makes essential the paper division in two parts in order to provide the most appropriate and valuable comprehension on what drives fir entry and what drives fir growth.

After a brief data description, the paper illustrates the patterns of fir entry with a deep analysis of the industry environment, the products and the entrepreneurs (Section 3). Section 4 highlights the drivers of fir post-entry growth, according to the rate of product differentiation, investments in co-specialised assets and geographic expansion. Section 5 concludes and summarises the main find ings.

\section{Description of data sources}

In this section, we provide an ex-ante, detailed description of the data we used, since we triangulate in the paper a wide range of data from different sources.

- Firm entry was assigned when a new ESI product was released on the market. Products introduction data were taken from Infotrac's General Business File ASAP database, downloading all the press articles that report a "Product announcement", a "New software release" and a "Software evaluation" in the security software sector. From this source we could extract the name of the company, the exact date of product introduction and the precise SIC code of the product.

- Information about alliances was drawn from Infotrac's Insite Promt database that, from a large set of trade journals, magazines and other specialised press, reports several categories of fir agreements like strategic alliances, licences, and product contracts. For the period 1993-1999 we downloaded all the events classifie under the SIC Code 73726 (Encryption Software Sector). With these data, we created a value-added database (we refer to it as the EVENT database) reclassifying data and introducing some new information like the passive or active fir role (acquirer or acquired, licensee or licenser, etc.) and the presence of a technological content in the agreement. We re-grouped the events in fi e broad categories: (i) technological alliances; (ii) distribution and marketing alliances; (iii) technological licences; (iv) product order contracts; and (v) mergers and acquisitions.

- Patent data are downloaded from the US Patent Offic web site. We considered all the patents granted in the US class 380 (Cryptography) that include "equipment and processes which: (a) conceal or obscure intelligible information by transforming such information so as to make the information intelligible to a casual or unauthorised recipient; or (b) extract intelligible information from such a concealed representation, including breaking of unknown codes and messages". ${ }^{2}$ For each patent we extracted all the information reported in the on-line front page of the patent (issue date, assignee, citations and inventors).

- Firm's financia data were taken from Hoover's, which collects data for the Security Software \& Services industry.

- Data on the structure of fir groups (including subsidiaries) were taken from Business and Company Resource Center database, Gale Group's Infotrac.

- Information on fir profile and histories, on biographical data of firm founders and managers were taken from Hoover's, Mergent-on-Line and Infotrac's ASAP $^{3}$ database.

\footnotetext{
${ }^{2}$ US Patent Offic classificatio manual, http://www.uspto.gov.

${ }^{3}$ For more details see the several notes in the text that cite the journal articles.
} 
We also conduct fi e interviews with managers of leading start-ups, precisely at Checkpoint, Baltimore, Aladdin and Network Associates.

\section{Entry process in ESI}

This section will show how the birth of ESI is mainly explained by start-up dynamics. Therefore, describing entry in ESI, we follow the approach of Gartner (Gartner, 1985), who proposed a useful framework to study new venture creation. The author highlighted three main field of analysis: the environment, the new product (or process), and the entrepreneurs. At this point of analysis, fir organisational characteristics could safely remain in the background; since they could often be seen as a combination of the firs three features (see Baron and Hanna, 2002). Consequently, the opening paragraph focuses on the environment.

\subsection{The environment}

Several researchers (Audretsch, 1991; Klepper, 1996; Shane, 2001) have confirme the importance of technological regimes in influencin the dynamics of entry. Especially in the fiel of entrepreneurship studies, we agree with Bhide (p. 31) that "start-ups can more easily turn a profi in some field then in others" (Bhide, 2000). First of all, the software industry is generally characterised by low entry barriers. Moreover, the industry underwent a process of market segmentation and fir specialisation that spurred the birth of several market niches and new firm (Torrisi, 1998). Given these features, the software industry appeared as a turbulent industry with a high rate of entry, exit, product innovation and imitation, where the low entry and exit barriers spurred fir birth and death more dynamically compared to other industries. In this sense, the software industry could represent the ideal environment to study and understand the birth of new market niches.

The early stages of ESI date back to the mid-1970s and the beginning of the 1980 s, when the US Government finance military projects linked strictly to the security of data transmission. Large ICT firm awarded these types of contracts and worked actively on software security architectures. At this stage, university departments, especially from Stanford and MIT, and government agencies also played a major role. Some firms such as Philips, NEC and Pioneer, were also involved in the design of the bulk of firs cable TV sets, which included the encryption and the decryption of cable signals through TV decoders. This is also evident from data in Table 1 where the most cited ${ }^{4}$ organisations that were granted a US patent in the 380 USPTO class in the period 1977-1992 were listed. We will discuss below the importance of patents in this USPTO class.

Lately, after more than 15 years, the huge development of Personal Computer market and Internet, especially Internet financia transactions, introduced new consumers and market needs that have spurred the proliferation of innovative products in the industry. ${ }^{5}$ Data provided by the International Data Corporation ${ }^{6}$ evaluated the world market of ESI 2.17 billion dollars in 1997 and 3.2 billion dollars in 1998, with an estimate of 4.4 billion dollars for the 1999 .

Fig. 1 shows the Hazard and Survivor functions calculated on the sample firm that entered the ESI market from 1989. ${ }^{7}$ The Hazard rate represents the percentage of exit among firm at risk of exit, while the Survivor rate is the percentage of survived firm (see Kiefer, 1988). The negative duration dependence of ESI data is a common findin in young industries with a massive $\mathrm{fl} \mathrm{w}$ of entry.

Fig. 1 does not show any sound firs mover advantage effect or any shakeout process in ESI. This is a quite sound proof that economies of scale in this industry do not play any significan role, given the low fi ed costs needed to start an ESI venture. For example, the initial amount invested to set up Check Point Software, the fourth largest fir in ESI at 1998, was US\$ $300,000 .^{8}$

The rising civilian demand increased the spectrum and the complexity of different products and services offered. Due to these changing conditions, young

\footnotetext{
${ }^{4}$ Backward citations from 1993-1999 sample patents.

${ }^{5}$ Rising E-commerce will drive Growth for Security Software Companies, Business Week, 7th April 2000, p. 6.

6 "Worldwide Internet Security Software Market to close in on 4.4 billion dollars in 1999", 1999. EDP Weekly's IT Monitor 40(32), 18.

${ }^{7}$ We defin an exit when a fir does not release any new product or new version of existing product after 2 years from the introduction of last product.

8 “Israel's Safety Net”, 1999. Electronic Business 25(5), 72.
} 
Table 1

Most cited assignees, granted patents 1977-1992

\begin{tabular}{llccr}
\hline Firm & Sector & Citations $(C)$ & Patents $(P)$ & $C / P$ ratio \\
\hline IBM & Computer & 528 & 46 & 11.47 \\
Motorota & Telecom & 226 & 24 & 9.41 \\
Scientifi Atlanta & Telecom & 202 & 18 & 11.22 \\
Pitney Bowes & Computer & 165 & 16 & 10.31 \\
Qualcomm & Electronics & 97 & 3 & 32.33 \\
AT\&T & Telecom & 97 & 8 & 12.12 \\
Pioneer & Electronics & 95 & 9 & 10.55 \\
Philips & Electronics & 95 & 7 & 13.57 \\
Aisin Seiki & Cars & 83 & 6 & 13.83 \\
Stanford University & University & 80 & 2 & 40 \\
M.I.T. & University & 75 & 2 & 37.5 \\
NEC & Electronics & 72 & 6 & 12 \\
General Instrument & Electronics & 68 & 8 & 8.5 \\
NCR & Computer & 63 & 5 & 12.6 \\
Hitachi & Electronics & 62 & 4 & 15.5 \\
VISA & Services & 53 & 2 & 17.5 \\
Total & & 2061 & 166 & 11.81 \\
Other & & 2520 & 224 & \\
\hline
\end{tabular}

Source US Patent Office

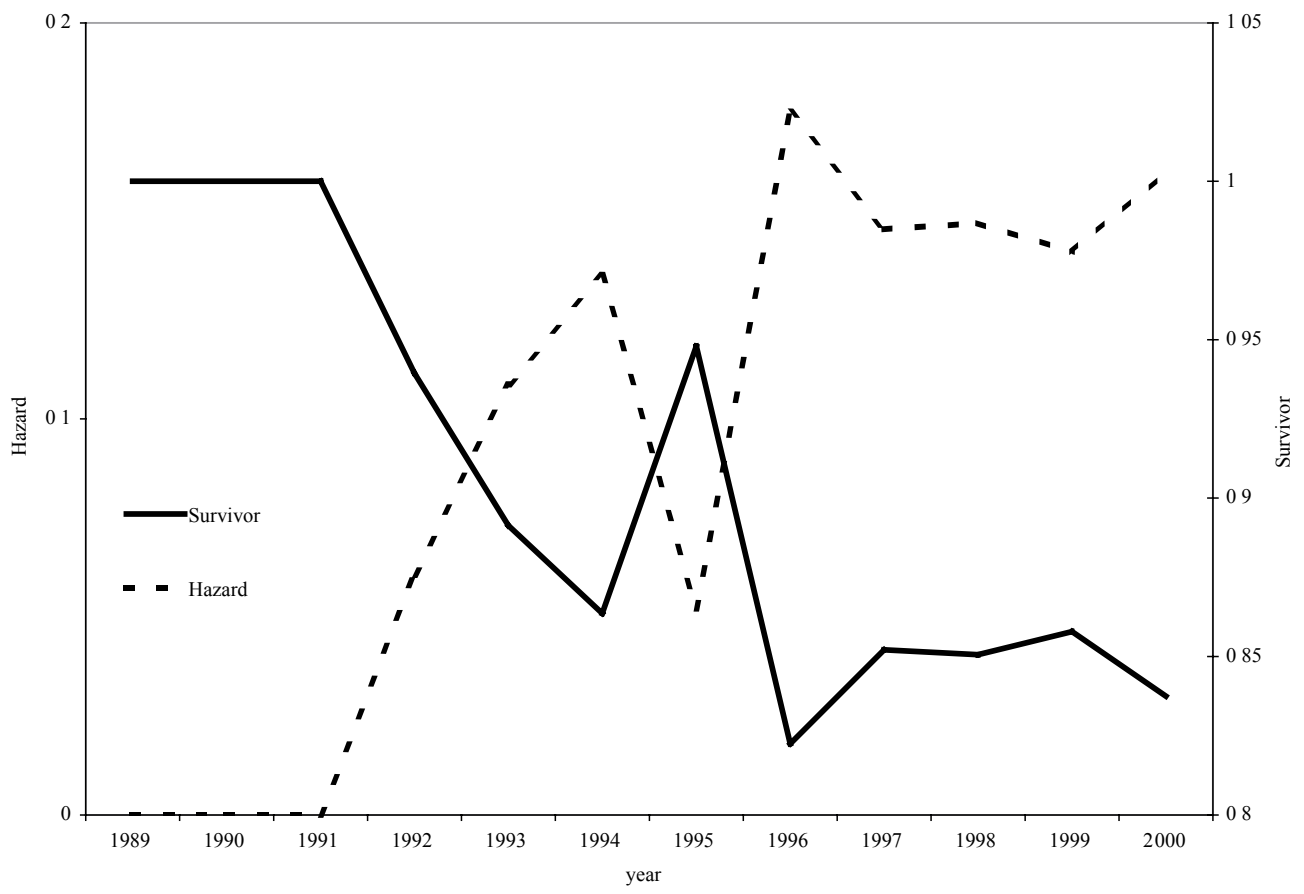

Fig. 1. Hazard and survivor functions, 1989-2000. 
Table 2

World market leaders in ESI at 1998

\begin{tabular}{clcllr}
\hline Rank & Firm & Revenues (US\$ in million) & World market share & Year of entry & Firms in the same entry cohort \\
\hline 1 & Network Ass. & 990 & 0.171 & 1993 & 18 \\
2 & Symantec & 578.4 & 0.099 & 1990 & 8 \\
3 & RSA Data Security & 171.3 & 0.029 & 1991 & 17 \\
4 & Check Point & 141.9 & 0.024 & 1995 & 35 \\
5 & Rainbow Tech. & 109.2 & 0.018 & 1998 & 56 \\
6 & Axent Tech & 101 & 0.017 & 1994 & 29 \\
7 & Trend Micro & 86.2 & 0.014 & 1991 & 17 \\
8 & Secure Computing & 61.4 & 0.010 & 1994 & 29 \\
9 & Entrust Tech. & 49 & 0.008 & 1997 & 57 \\
10 & Cylink & 42.8 & 0.007 & 1995 & 35 \\
11 & SystemSoft & 42.6 & 0.007 & 1998 & 56 \\
12 & VeriSign & 38.9 & 0.006 & 1998 & 56 \\
13 & BindView & 38.5 & 0.006 & 1995 & 35 \\
14 & Aladdin & 36.1 & 0.006 & 1997 & 57 \\
15 & Safenet & 23.2 & 0.005 & 1998 & 56 \\
Total & & 2487.3 & 0.429 & & \\
\hline
\end{tabular}

Source IDC Corporation, Infotrac.

small ventures were better suited to exploit these opportunities. Table 2 shows the world market leaders in ESI at 1998, 10 years after the frst product was introduced on the market. It is worth noticing that all these f rms were start-ups in ESI. As in other industries (Henderson, 1993), ESI represents a classical example where start-ups are the organisation forms that better adapt to young turbulent environments. As previously noted, this evidence leads us to focus mainly on the role of start-ups in ESI, leaving the study of incumbent strategies to further works.

The industry offers now a wide selection of products going from the basic products of encryption, such as Firewall and Anti-virus programs to advanced security services like Public Key Infrastructures, Security Certif cation and Virtual Private Network. Table 3 shows the most important product niches of ESI, ac-

Table 3

Product niches in ESI

\begin{tabular}{lc}
\hline Description & SIC code \\
\hline Authentication Digital Signature & 7372663 \\
Anti-virus & 7372612 \\
Data storage protection & 7372691 \\
Firewalls & 7372681 \\
Utility software & 7372614 \\
Network Software Security & 7372611 \\
Virtual private network access & 7372613
\end{tabular}

Source Infotrac. cording to SIC code division. Generally, these products are software packages strengthening boundaries between networks and protecting computers against viruses and unauthorised users. They also integrate at the same time network access control, authentication, security, and policy management. The product functions aim not only to assure the secrecy and protection of data and data transmission against possible privacy attacks from outside, but also to provide verif cation and testing of possible intrusions and sabotages from inside.

The design of the general security protection of an information system is now a complex project and it incorporates problem solutions from different technological felds such as mathematics, software, hardware and network design. According to the CEO of a provider of security software solutions: "security policies are hard to design, hard to update, hard to enforce, and hard to make practical".

Besides the low initial sunk costs, ESI was also characterised by initial low entry barriers from the technological point of view; the breakthrough innovations were protected by patents granted about twenty years before the rise of the industry. New $\mathrm{f} \mathrm{rms} \mathrm{could}$ easily and with no costs base their product architectures upon those patents without paying any royalties.

\footnotetext{
${ }^{9}$ Wilbanks, J., CEO of SecureWork. In: "Managing Managed Security”, Information Security, January 2001, p. 12.
} 
Table 4

Citations and granted patents cited by "1993-1999" patents (backward citations), 1976-1984

\begin{tabular}{lccc}
\hline Year & Citations $(C)$ & Patents $(P)$ & $C / P$ ratio \\
\hline 1976 & 19 & 2 & 9.5 \\
1977 & 194 & 7 & 27.71 \\
1978 & 110 & 7 & 15.71 \\
1979 & 50 & 5 & 10 \\
1980 & 189 & 19 & 9.94 \\
1981 & 167 & 14 & 11.92 \\
1982 & 160 & 14 & 11.42 \\
1983 & 165 & 12 & 13.75 \\
1984 & 181 & 16 & 11.31 \\
Average & 137.22 & 10.66 & 13.47 \\
Average 1985-1992 & 552.5 & 250.5 & 2.20
\end{tabular}

Source US Patent Off ce.

In Table 4, we include the number of patents cited by all patents granted in the period 1993-1999 and their number of citations; it is not diff cult to observe the importance of the patents granted from 1976 to 1984 compared to the others (see $C / P$ ratio). ${ }^{10}$ Furthermore, the two most cited patents were granted by to public institutions like MIT and the Stanford University.

The survival rate of $\mathrm{f}$ rms that entered the market was low, especially in the frst periods; the survival post-entry average rate is $19 \%$ after a year and $10 \%$ setting the 2000 as the $\mathrm{f}$ nal year. This evidence is striking compared for example to data in manufacturing industries (Dunne et al., 1988), where the survival rate equals to $50.4 \%$ after 5 years and $13 \%$ after 15 years.

The high exit rate could be explained by two important factors: frst by low exit barriers and secondly by the uncertainty about the quality of the product. In fact, only after a proved resistance against several attacks, the product could be considered effective. This implies that an initial, even casual, bad performance of a new product could be fatal to the producer, even if the product was substantially a good one (Smith, 1999).

Some concluding remarks: the process that spurred the birth of the ESI was characterised by demand pull conditions, but the particular technological core of the

\footnotetext{
${ }^{10}$ It is worth noting that on average the patents cited in the period $1976-1992$ are $19.03 \%$ of the total patents granted in those years in the 380 class.
}

products and the presence of high skilled customers generated selective selection phenomena, especially in the earlier years, where only few new ventures were able to survive. To have a better idea of the factors that lie behind the survival capability of $\mathrm{frms}$, we need now to describe the main features of ESI products.

\subsection{The products: algorithms and software packages}

Chrisman et al. (1998) pointed the ability of $\mathrm{frm}$ survival the effective measure of $\mathrm{f}$ tness in the context of entry by new $\mathrm{f} \mathrm{rm}$ formation. Along this view, the common, and perhaps the only, aim of a new venture in the frst stages of its life is working as a self-sustaining economic activity (Kazanjian, 1988; Hanks and Chandler, 1994; Wagner, 1994). Given the high rate of sudden f rm mortality after entry in ESI, we consider essential studying the preliminary selection factors among frms. In so doing, a "meticulous" comprehension of what is an ESI product is required.

Among all the different technologies required in a standard ESI product, the key feature is the crypto-algorithm that specif es the mathematical transformations that are performed on data. A crypto algorithm is a procedure that takes the plain text data and transforms it into cipher text. The process could be reversed with a secret key. The right balance between communication speed requirements and security protection is what assures the quality of the product. In fact, the time consumed by encrypting and decrypting processes depends on the length of mathematical algorithm and on the power of computing machines (Smith, 1999).

The crypto algorithm is the principal object of a $\mathrm{frm}$ 's patent. This is mainly due to the recent trend of US Patent Off ce to loosening restrictions that had been placed upon patent applications directed to software inventions. Contrary to the previous discipline, mathematical algorithms could now be examined with respect to their novelty, non-obviousness and utility (Gosnell, 1999; Bessen and Hunt, 2003). Mathematical and software engineering capabilities represent indeed the core competences needed in the production of ESI products. The USPTO 380 class, "Cryptography", is the strategic technological f eld for ESI. It could be the case that some frms were granted patents related to these technological competencies in classes different from the 380 . Nevertheless, the class 380 accounts 
for the bulk of inventions in cryptography; it is worth noting that all start-ups that dominate the sector (see Table 2) have not been granted any patents outside this class by 2000 .

At the very beginning, small frms entered specialised in a well-def ned product area like, for example, Checkpoint and Axent in Firewall; Network Associates, Symantec and Trendmicro in Anti-virus software; Certicom, Entrust and Cyberguard in Virtual Private Network architecture; Baltimore in digital signature protocols. From interviews with start-up executives we conducted, it emerged clearly the importance for start-ups to build up reputation on a specif $\mathrm{c}$ product. A manager of a $\mathrm{frm}$ leader in ESI aff rmed: "At the beginning, the great idea was to transform a complex technological invention in a user friendly product off-the-shelf. It should be easy to install and use. Our f rm based its success creating the Firewall as now we know it". The origin of ESI was basically a story of good innovations: a f rm survived if it introduced a sound technological product. Consequently, the major causes of a frm's survival (or mortality) was the quality of the product, that is a combination of mathematical algorithm, case sensitive intrusions knowledge and software adaptability. For this reason, the success means simply the ability to propose a product with a sound mathematical core that adapts to different software platforms and preserves the speed of data transmission. In Box 1, we include three examples of successful start-ups product introduction.

These three examples help understand two important points: frst, the importance of the quality of innovation and of the technical capabilities of the entrepreneur. Second, the important role of the patent protection in this industry, since all these three mathematical algorithms are strongly protected by patents. In fact, innovation and imitation have always represented essential strategic variables in the high-tech industries and intellectual propriety rights play a key part in protecting $\mathrm{frm}$ competitive advantages (Arora et al., 2001). Nonetheless, patents are usually not seen as good instruments (Cohen et al., 2000) to protect software innovations from imitation, and $\mathrm{frms}$ had often utilised other privacy techniques such as tacitness and secrecy. However, we would like to stress again that ESI represents a special case where patents do protect against possible imitation, thanks to the importance of mathematical algorithms.
Box 1. Start-ups and innovative products in ESI

- Checkpoint created an innovative process to built $\mathrm{f}$ rewalls, security products that could go directly off the shelf to a customer and that enforce the boundaries between different networks and protect $\mathrm{f}$ rms against unauthorised users. Checkpoint's programmers introduced a new language, Inspect, specif cally for directing the rapid inspection of communication packets and a compiler to translate policy rules written in Inspect into assembly language. The program opens data packets, checks the content and quickly inspects each data packet. The innovation is that the program sends along the data in parcels after they are checked, rather than waiting to reassemble them before the entire transmission. This methodology increased dramatically the speed of data transmission, with the same level of security. ${ }^{11}$

- Geoffrey Rhoads, a physicist and founder of Digimarc, created the core Digimarc technology when he was working on a camera for cleaning up digital spaces images photographed through ground-based telescopes. Rhoads reversed the imaging fltering process and added a micro ownership mark to the photos. The technology could imperceptibly include digital data in visual content (like movies and photos) and valuable documents such as f nancial data-sheets and passports. In addition, Rhoads introduced a method that allows the identif cation of a copy of an original signal from the original signal. This can be achieved by modulating the source code with a small "noise" code that could be cancelled in case of a copied product. ${ }^{12}$

\footnotetext{
11 "Safe at 100 megabits/s. Check Point Software Technologies creates Internet f rewall which supports high speed transactions", Forbes, 30 December 1996, p. 138. See also US Patent 5,835,726, fled in 17th June 1996, by Shwed, G., et al., "System for securing the fow of and selectively modifying packets in a computer network".

12 "Trolling the net. Digimarc's watermarking technology", September 1998. Electric Bussiness 24(9), 60. US Patent $5,710,834$, fled in 8th May 1995, by Rhoads, G., "Method and apparatus responsive to a code signal conveyed through a graphic image".
} 
- Certicom's Elliptic Curve Cryptography is a technology especially useful in what is known as "small-footprint environments" such as smart cards or wireless communications devices, where space is the scarcest resource. If the standard string of computer bits necessary to encode or decode an encrypted message needs about 1,024 bits, Certicom's system accomplishes in 160. The difference is rooted in mathematics. ${ }^{13}$ In fact while the standard cryptographic systems are based on integer calculus, the elliptic curve cryptosystem uses equations that can be calculated more easily and faster. ${ }^{14}$

In fact, the core of security products is the mathematical procedure that lies behind the encryption of data. For example, Entrust Technologies, one of the leading innovators in the feld, is responsible for over 90 patents and pending patent applications. ${ }^{15}$

Given the importance of patents in protecting algorithms, it could be useful to provide more specif c information on what is the content of a typical patent in 380 USPTO class. Ronald Rivest, a former researcher at MIT, invented one of the most famous and widespread crypto algorithms at the RSA Data Security. This invention is protected by the USPTO patent 5,724,428, entitled "Block Encryption Algorithm with Data-dependent Rotations". This patent document includes: four fow charts reporting step-by-step the encryption-decryption routines and the detailed description of all the mathematical procedures that perform the encryption. Moreover, there are also some f nal considerations about how the length, in terms of bits, of the secret key (the usual password) affects the level of security and the speed of the cipher process.

Thus, patents protect mainly two separated things: (1) the structure of the sequences of steps and routines of the encryption process; and (2) the mathemat-

\footnotetext{
${ }^{13}$ A classical form of an elliptic curve is $y^{2}+x y=x^{3}+a x^{2}+b$.

14 "Cheaper encryption tool gaining momentum. Certicom Corp.'s elliptic curve cryptosystem", American Banker, 2 April 1997, p. 12. US Patent number 6,141,420, f led January 29th 1997 , by S. Vanstone et al., "Elliptic curve encryption system".

15 "Network Magazine Names Entrust/PKI(TM) Software 2001 Product of the Year", Market News Publishing, 8 June 2001, p. 10.
}

ical procedures that lie behind them. Software code is not mentioned in the patent document and so it is not protected. The mathematical algorithm represents, therefore, a form of general-purpose technology (Bresnahan and Trajtenberg, 1995), which could be run and used on different software packages and applications (i.e. e-mail clients, compressing programs and Internet browser).

Mostly thanks to this effective patent protection, ESI market could be classif ed into two sub-markets: (i) a market for the standard products of ESI (Firewall, Anti-virus, etc.); and (ii) a market for technology, where frms could acquire the right to use the proprietary mathematical algorithm patented. Fig. 2 shows a graphical representation of the two sub-markets. As we can see, the mathematical algorithm could be used in several in-house research projects or for the production of third-party products.

In terms of market size, Hoovers data show that in 2000 for the top 15 start-ups in ESI (see Table 2) 56.6\% of revenues comes from sales of product software, $28,3 \%$ from services and $14,9 \%$ from licensing the technological algorithm.

From our EVENT database, between 1993 and 1999, we collected 119 "Technological License Agreements" and 143 "Product Order Contracts". Technological License Agreements include only contracts where the object of transaction is the mathematical algorithm; while Product Order Contracts represent the classical supply of off-the-shelf software products among f rms (we excluded the business to customer contracts). ${ }^{16}$ These two events could be considered good proxies for the two types of markets. The most important buyers and sellers, for number of technological licenses and product contracts awarded, are ranked in Table 5. We would like to stress that Product Order Contracts and Technological Licenses Agreements are usually not the two faces of the same contract. On average, in the $92 \%$ of cases, for each $\mathrm{f} \mathrm{rm}$, the product order contract is not included in the technology licensing agreement.

Concerning the licenses, the most important seller of technology, among 53 different sellers, is RSA Data Security with 23 licensing contracts signed (19.3\% of total licenses concluded). Among 105 different f rms,

\footnotetext{
16 This distinction is fundamental to avoid confusion; in fact a software product is often sold in term of number of licences.
} 


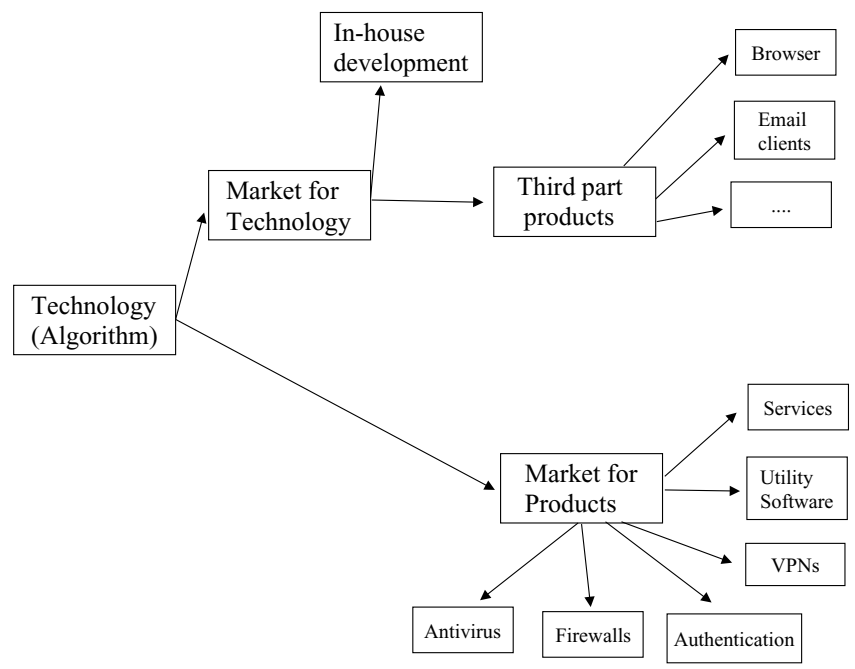

Fig. 2. The market for products and for technologies in ESI.

Table 5

Main buyers and sellers of products and technology in ESI, 1993-1999

\begin{tabular}{llrlr}
\hline Technology licenses & & & \\
\hline Rank & Main licensors & No. & Main licensees & No. \\
\hline 1 & RSA Data Security & 23 & IBM & 12 \\
2 & Certicom & 13 & H\&P & 8 \\
3 & Network Ass. & 10 & Time Warner & 4 \\
4 & Entrust & 5 & Microsoft & 3 \\
5 & Check Point & 4 & Compaq & 4 \\
6 & Macrovision & 4 & NEC & 3 \\
7 & VeriSign & 4 & Network Ass. & 3 \\
8 & Diversinet & 2 & Lucent & 3 \\
9 & Cylink & 2 & Rainbow Tech. & 3 \\
10 & Finjan & 2 & Secured Comm. & 2 \\
Product & order and contracts & & & \\
\hline & Main sellers & & Main buyers & \\
\hline 1 & VeriSign & 10 & Verizon & 6 \\
2 & RSA Data Security & 8 & IBM & 5 \\
3 & Secure Computing & 5 & H\&P & 4 \\
4 & Check Point & 4 & Visa & 4 \\
5 & Network Ass. & 4 & NSA & 2 \\
6 & Cylink & 4 & Infonet & 2 \\
7 & Entrust & 4 & KPMG & 2 \\
8 & Cisco Systems & 4 & Microsoft & 2 \\
9 & Axent & 4 & Time Warner & 2 \\
10 & Baltimore Tech & 4 & Sun Microsystem & 2 \\
& & & &
\end{tabular}

Source EVENT database. the most important buyer of the technology is IBM ( $8.3 \%$ of total contracts). These data show that leading start-ups are dominating both the market for products and the market for algorithms.

In most cases, a technology buyer utilises the crypto algorithm in two ways: or to develop new proprietary in-house innovation from the technology acquired or to directly include the algorithm in an already existing product. In Box 2, we present two standard examples of Technological Licenses Agreements to explain the nature of this agreement and to highlight the specif city of this "market for algorithms" in ESI.

In conclusion, two factors were common among the most successful f rms: the frst is that they entered by specialising in a particular niche. Secondly, successful start-ups entered with a distinguished innovative product. Interestingly, the empirical evidence seems to conf rm a strong interdependency between the technological and the product sub-markets. The Pearson correlation coeff cient between product orders and technological licenses awarded by $\mathrm{frm}$ and by year equals 0.68 , with a signif cance level of $5 \%$. This high correlation supports the thesis that, especially in the f rst years of industry evolution, innovation played a major role. A good mathematical algorithm that gives f rm success in the market for technologies seems to be a necessary condition for gaining a competitive 
Box 2. Technology licensing contracts and their applications

- In-house development: In 1995 VLSI Technology licensed RSA Data Security's RC4 Symmetric Stream Cipher encryption algorithm and embedded it on its own processor and memory cores. VLSI aimed to combine its processor with RSA technology in order to sell an innovative product to AT\&T Bell Laboratories for the production of a new data encryption system. ${ }^{17}$

- Third-part products: In 1997, VeriFone obtained the rights to use the "Elliptic Curve Algorithms" for smart cards by licensing the patent from Certicom. VeriFone will use the technology for its Personal ATM and VeriSmart System devices for downloading money into smart cards. ${ }^{18}$

advantage in the market for products. Moreover, the fact that the same large ICT $\mathrm{frms}$ are the major buyers in the two sub-markets conf rms the importance of the role played both by high skilled consumers and by the quality of product innovation. The interaction between market focus and product innovation has been already spotted in the literature (Vinnell and Hamilton, 1999) as one of the key factors of survival in the early stages of a new business. Firm entry with an innovative and sound idea in a particular product area could create a strong reputation effect and sustain a competitive advantage in the preliminary phases of competition (Kazanjian and Rao, 1999). This means that specialised entry it is not a suff cient condition to guarantee $\mathrm{f} \mathrm{rm}$ survival, especially in high-tech sectors. It is the quality of product technologies combined with the business market focus that increase start-up reputation and prof tability. The empirical evidence seems to con$\mathrm{f} \mathrm{rm}$ this point. Among the 200 out-gone $\mathrm{frms}$ in ESI from 1989 to 2000 only $3.5 \%$ were granted a patent at USPTO. Results do not change introducing the age variable: comparing similar entry cohorts, among the

\footnotetext{
17 "VLSI to embed RSA encryption under license", 16 January 1995. Electronic News 4(1), 60.

18 "VeriFone to license new encryption engine", 30 June 1997. PC Week 14(28), 53.
}

87 exit $\mathrm{f}$ rms that survived at least 4 years, only $5.7 \%$ were grated a patent. ${ }^{19}$ On the other side, $73 \%$ of survived f rms by 2000 with more than 4 years of the presence on the market were at least assignees of a patent.

\subsection{The entrepreneurs}

In the $\mathrm{f}$ rst periods of a new $\mathrm{f}$ rm life, the $\mathrm{frm}$ and its entrepreneur were often indistinguishable (Meyer and Roberts, 1986; Terpstra and Olson, 1993). According to Gartner (Gartner, 1985), the points of strength and weakness of a new venture are at the beginning those of its founder. It is consequently quite obvious that the probability of $\mathrm{frm}$ success depends strongly on founder's competencies and abilities (Holmes and Schmitz, 1990). The high heterogeneity among start-ups is mainly due to different entrepreneur approaches in exploiting same business opportunities. Very intriguingly Baron and Hanna (2002) found from a 200 start-up survey in Silicon Valley that "founders embraced very different mental models of the ideal organizational form" (p. 9).

Cast under this light, $\mathrm{f} \mathrm{rm}$ founder characteristics are critical to assess what capabilities they brought inside their company, what incentives they had, what business idea they $\mathrm{ftted}$ in the organisation and how they shaped the $\mathrm{frm}$ in the initial stages. Blanchower and Oswald (1998) recognise in the presence of a valuable type of information or capability the key element in the nature of an entrepreneur. This means owning $\mathrm{f}$ rst information regarding the creation and evaluation of a business opportunity, and then information linked with the capability to exploit the business opportunity (Shane and Venkataraman, 2000). In other words, in order to exploit an opportunity, an entrepreneur should possess information about specif $\mathrm{c}$ aspects of production and about user needs (Hippel von, 1988). While the latter refers to the ability to tailor business ideas towards possible specif c customers (f nd or build a market), the former is properly linked to the typology of the entrepreneur. At this regard, there are three main entrepreneurial typologies: the innovator, who creates new products; the arbitrageur, who exploits market ineff ciencies and the coordinator, who introduces an

\footnotetext{
${ }^{19}$ Note that this industry at 2000 could count only on 11 years of life.
} 
alternative use of resources (Bhide, 2000; Shane and Venkataraman, 2000).

In Table 6, the founder's origins of the 15 largest start-ups were listed. The more evident regularity is that more of $50 \%$ of top start-up founders were employees of a large ICT frms (53\%). The remaining $35 \%$ were former government or university researchers and last, $12 \%$ were former founders or employees of other software start-ups. Successful $\mathrm{f} \mathrm{rm}$ founders have gained some advantages while working for large ICT f rms or government-academic institutions. In fact, these two organisations represented the producers of the basic technology of the sector (see Table 1) and the main users of these products (see Table 2).

As a matter of fact, we could suppose that these entrepreneurs could have been subject to some learning processes about the basic technologies (how to innovate) and user's needs (how to exploit). According to this view, Klepper and Sleeper (2000) introduced the term of "heredity" that spin-offs received from the par- ent $\mathrm{frm}$ especially when there is some knowledge embedded in human capital. For example, in the automobile industry, Klepper (2001) highlights how spin-offs from incumbents f rms have a high probability of surviving and growth.

It is interesting that among the 18 entrepreneurs coming from ICT incumbents and universities, $72 \%$ are assigned at least one patent at USPTO (Table 6). In this sense, their fundamental entrepreneurial competence was the ability to exploit mathematical skills linked to the ability of software compiling and design. Moreover, it is worth noting that among these founders-inventors, $61 \%$ were also assigned a patent before starting their company, when employed in a R\&D laboratory of a large ICT f rm or university.

Firm founders in ESI are typically innovators, because it is an innovation that has pushed them to set up a new venture.

In Box 3, we collect some useful cases to support this hypothesis.

Table 6

Founders of top 15 start-ups and their origins

\begin{tabular}{llll}
\hline Firm & Founder & Patent assignee & Former founder's employer \\
\hline Large Firms & & \\
Certicom & P. Panjwani & $\checkmark$ & Motorola \\
Cylink & L. Morris & & Xerox \\
Entrust Tech. & B. O'Higgins & $\checkmark$ & Nortel \\
Network Ass. & W. Larson & $\checkmark$ & Apple and Sun Microsystem \\
Network Ass. & J. McAfee & & Lockheed Martin \\
Rainbow Tech. & W. Straub & & IBM and Compaq \\
RSA Data Security & C. Stuckey & $\checkmark$ & MIT, Pitney Bowes \\
RSA Data Security & R. Rivest & $\checkmark$ & Computer Ass. \\
Safenet & A. Caputo & $\checkmark$ & Honeywell and Motorola \\
Secure Comp. & K. Beseke & $\checkmark$ & H\&P \\
Trend Micro & S. Chang & & \\
Small frms & & & Network Research, systems integrator \\
BindView Dev. & E.J. Pulaski & & Phoenix Technologies, a software producer \\
SystemSoft & R. Angelo & & RSA Data Security \\
VeriSign & J. Bidzos & & University of Waterloo \\
University and Public Research Laboratories & S. Vanstone & $\checkmark$ & Hebrew University \\
Certicom & Y. Margalyt & $\checkmark$ & Optrotech, Israel Defence Forces \\
Aladdin & G. Shwed & $\checkmark$ & Optrotech, Israel Defence Forces \\
CheckPoint Software & M. Nacht & & Mathematician \\
CheckPoint Software & A. Jennings & $\checkmark$ & National Security Agency \\
Rainbow Tech. & A. Hastings & $\checkmark$ & Stanford University \\
Safenet & G. Hendrix & & \\
Symatenc & & &
\end{tabular}

Source Hoover's and US Patent Off ce. 
Box 3. Firm founder origins

- B. O'Higgins, the founder of Entrust, has overall responsibility for the technology vision and direction for the company. He was previously with Nortel where he established the Secure Networks group in 1993 and with BNR-Bell Northern Research, which he joined in 1979. At BNR, he was involved with a variety of technology development programs, including public key security systems, technology for new telephone products, in-building wireless communications systems and high performance computing architectures for call processing applications. ${ }^{20}$

- A. Vanstone, the founder of Certicom, was a professor of Mathematics, and he has published more than 150 research papers and several books on topics such as cryptography, coding theory, f nite geometry, and combinatorial designs. ${ }^{21}$

- Prior to launching Trend Micro, S. Chang worked as an engineer in the R\&D laboratories of Hewlett-Packard. He received his B.S. in Applied Mathematics and his M.S. in Computer Science. He founded Trend Micro in 1988 with the mission of developing anti-virus software for personal computers, with a company's focus to address total network security. ${ }^{22}$

To conclude this section, the link between innovation and new $\mathrm{frm}$ formation was the major issue presented, where innovation was the key to open new market niches, avoiding potential entry barriers. Then, entrepreneur characteristics were fundamental to understand start-up performance especially during its frst years, because ESI was a classical case study where inventors become entrepreneurs. We then stressed the importance of patents as a tool to defend

\footnotetext{
20 "Network Magazine Names Entrust/PKI(TM) Software 2001 Product of the Year", Market News Publishing, 8 June 2001, p. 34.

21 "Certicom's Founder Receives Security Award for Mathematics from RSA", Market News Publishing, 11 June 2001, p. 100.

22 "Behind-the-scenes attack on the virus plague. Steve Chang, Founder of Trend Micro", The Financial Times, 7 June 2000, p. 8.
}

f rm knowledge assets, an aspect quite remarkable in the software industry. In ESI, patents helped to build a market for technology that was essential in shaping competitive outcomes. This is also highlighted by the presence of two separated markets for software products and mathematical algorithms.

\section{The drivers of start-up growth}

In the previous sections we have highlighted the main factors beyond $\mathrm{f}$ rm entry, while here we draw attention on the $\mathrm{frm}$ growth process.

Firms survived from f rst competitive shocks faced new challenges. Empirical studies (Audretsch, 1991; Geroski, 1995; Klepper, 1996) have found how size and age positively affect the capacity of surviving of new entrants. In the case of ESI, Table 2 shows that top 15 start-ups have different entry times (see Table 2) and Fig. 1 that $\mathrm{frst}$ mover advantage effects are insignif cant. Therefore, f rm age does not seem a powerful discerning variable.

On the other hand, clearly size, growth and survival are strictly correlated. The research challenge of this section relies in disentangling the drivers of start-up growth in an industry where scale economies and sunk costs are negligible.

The more the time a f rm is able to remain on the market, the more is the number of requirements, information and feedbacks that it should elaborate. In fact, some scholars (Pavitt, 1988; Dodge et al., 1994) have noted that young $\mathrm{f} \mathrm{rm}$ evolution is linked with the $\mathrm{f} \mathrm{rm}$ capacity to deal with an increasing level of complexity. Especially in ESI, from an initial phase mainly based on technological advantages, the competition moved towards a multifaceted dimension. Most of the ESI start-ups experienced that being technologically at the frontier was not a lasting suff cient condition to growth. Following the entrepreneurship literature (see for example Vinnell and Hamilton, 1999), we highlight below two main issues that are conventional in explaining young $\mathrm{frm}$ growth. These factors are: (i) product differentiation; and (ii) international expansion linked with investments in co-specialised assets. In analysing them, we remind that the interactions between these factors and frm size are correlated and not linear (for example, the more a $\mathrm{f}$ rm offers a broad range of products, the more it ac- 
cesses to new international markets, the larger will be its size).

\subsection{Product differentiation}

Product differentiation is one of the main channels that strengthen f rm competitive advantages. Firms selling a broad range of products are in a better position to gain high margins, to increase their costumer base, to process and screen more information about market trends. Two main orders of motivations sustain the f rm broadening of product variety: demand side factors and $\mathrm{frm}$ strategic factors (Lancaster, 1990).

Tailoring products on customer preferences with product differentiation favours the reduction of sales uncertainty and the achievement of higher market shares. Along this view, empirical works have conf rmed a positive relationship between market share and product line breadth (Kekre and Srinivasan, 1990). For example, in a study on the computer workstation industry, Soreson (2000) has recently found that product variety strongly affects the probability of a f rm's survival.

The second type of factors refers to the strategic utilisation of product differentiation against potential competitors. Firms could offer a broad product variety as a strategic barrier to pre-empt new specialised markets entrants, especially when scale economies are modest. Lancaster (1990) studied product variety as a tool to saturate the product space in order to deter entry. This is an essential point to understand how product differentiation could affect $\mathrm{f}$ rm performances in software industry. We will see that when scale economies do not play a major role as in ESI, the range of product portfolio becomes one of the most critical variables to obtain and defend a competitive advantage.

Looking at product data on a time scale dimension, Table 7 shows the number of different versions of products in each niche in two sub-periods. There is evidence of an increasing product proliferation, linked with the rise of the software packages tailored to network design and security.

Fig. 3 shows that ESI evolution is characterised by two trends: as the ratio between products and f rms increases (less f rms, more products) the average $\mathrm{f} \mathrm{rm}$ diversif cation increases, and otherwise. It seems that waves of specialised entrants, that increase the level
Table 7

New products by market niche in ESI, 1989-95 and 1996-2000

\begin{tabular}{lcc}
\hline Description & \multicolumn{2}{c}{ Number of products in years } \\
\cline { 2 - 3 } & $1989-1995$ & $1996-2000$ \\
\hline Authentication-Digital Signature & 26 & 39 \\
Anti-virus & 21 & 11 \\
Data storage protection & 104 & 207 \\
Firewalls & 7 & 89 \\
Utility software & 15 & 22 \\
Network Software Security & 39 & 340 \\
Virtual private network & 0 & 242 \\
Other & 23 & 83 \\
Total & 235 & 1033 \\
& Concentration index \\
\cline { 2 - 3 } Herf ndhal & 0.253 & 0.214 \\
C2 & 0.608 & 0.529 \\
\hline
\end{tabular}

Source Infotrac.

of average frm product specialisation, are followed by periods of market consolidation where specialised f rms leave the market, and companies with a broader product variety survive.

Moreover, it is worth noting that the average Herf ndahl index calculated on the product portfolio of the survived f rms at 2000 equals to 0.741 , while the Herf dahl index for out-gone f rms is 0.924 (the two values are statistical different, $T$-test $=8.793$ ). Introducing $\mathrm{frm}$ age, the Herf ndahl index for the 87 exit $\mathrm{frms}$ that survived at least 4 years is equal to 0.867 , while for the survived $\mathrm{frms}$ by 2000 with more than 4 years of life is $0.694(T$-Test $=13.715)$.

The average Herf ndahl is computed across different product niches according to Table 3 . Using the total sample, Pearson correlation coeff cient between $\mathrm{f}$ rm duration on the market and $\mathrm{frm}$ level of product differentiation (Herdindahl index) equals -0.71 , with a signif cance level of $5 \%$.

Herf ndahl index for the top 15 start-ups (see Table 2) equals to 0.265 for the period 1989-1995 and 0.174 for the period 1996-2000, highlighting an increasing product differentiation of the market leaders. Data seem to conf rm that out-gone f rms remained product specialised, while f rms that survived adopted product differentiation.

If in ESI competing with a broad product selection is considerably correlated with f rm survival capabilities, it will be extremely interesting to understand how 


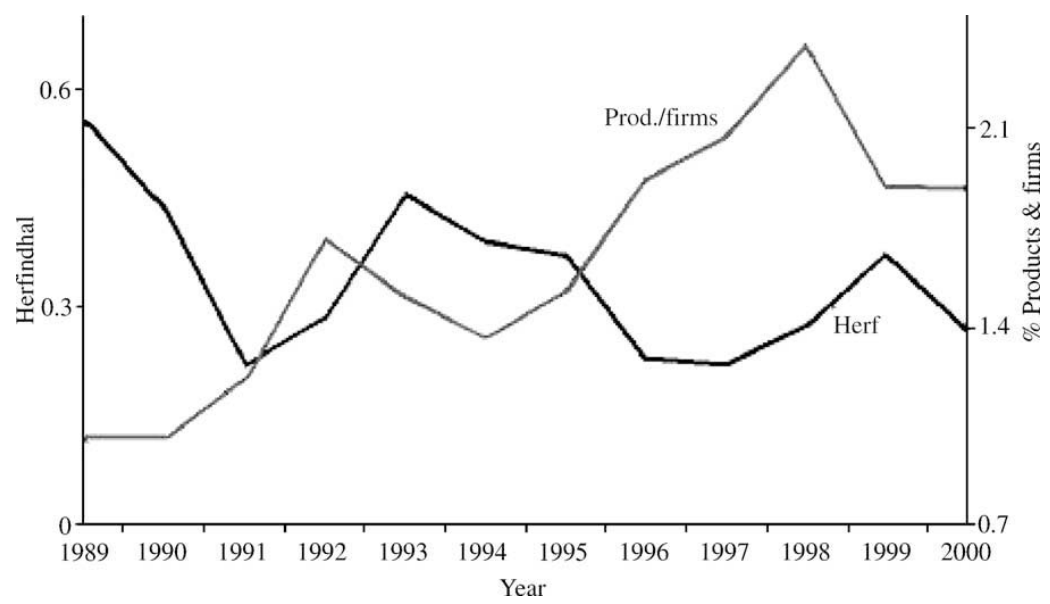

Fig. 3. Number of products standardised by number of f rms compared to average f rm diversif cation index, 1989-2000.

a f rm, born specialised in a particular niche, could have succeeded in expanding its product range. We would like to stress that every f rm entered in ESI was specialised in a particular product niche and there is not a case of a f rm that entered with a diversify product portfolio. In this context, alliances and mergers and acquisitions (M\&As) are important sources of knowledge and resources, especially for young small f rms (see Stuart et al., 1999; Baum et al., 2000). We analyse these two aspects in the next paragraphs.

\subsubsection{Technological alliances}

The in-house development of new products is based on the exploitation of economies of scope from the f rm knowledge resources (Teece, 1986). As a matter of fact, young frms often do not own all the technical competencies needed to develop new products. Recently f rms have exploited technological alliances as useful tools to quickly learn new technological competencies and exploiting research synergies. Empirical works on technological alliances reached the conclusions that collaborative ventures are useful to determine the product innovativeness especially for small frms (Kotabe and Swan, 1995). Stuart et al. (1999) found that alliances generate positive effects on young companies beyond other f rm characteristics, especially with large incumbent partners. Sakakibara (Sakakibara, 1997) showed that alliances are more productive if partners have complementary technolog- ical skills. Empirical works have already established that the mechanisms sustaining f rm growth in networks are highly correlated with the internal growth ones (Riccaboni and Pammolli, 2001). The importance of technological alliances should be correlated with the high technological core of ESI product, as discussed in great length in previous sections. In this sense they represent a valuable proxy of $f r m R \& D$ strategies in the context of product development (see for example Anand and Khanna, 2000). From the EVENT database, during the period 1993-1999 we collect 256 collaborative ventures in ESI with the aim

Table 8

Top f rms for number of technological alliances in ESI, 1993-1999

\begin{tabular}{llll}
\hline Rank & Firm & $\begin{array}{l}\text { Alliances } \\
\text { (a) }\end{array}$ & $\begin{array}{l}\text { a/Sales } \\
\text { (US\$ mil.) }\end{array}$ \\
\hline 1 & RSA Data Security & 39 & 0.406 \\
2 & Microsoft & 27 & 0.002 \\
3 & Check Point Soft. & 19 & 0.273 \\
4 & Network Ass. & 18 & 0.053 \\
5 & VeriSign & 17 & 0.167 \\
6 & H\&P & 14 & 0.000 \\
7 & Time Warner & 13 & 0.005 \\
8 & Internet Security & 12 & 0.230 \\
9 & IBM & 12 & 0.000 \\
10 & Entrust Tech. & 11 & 0.235 \\
& Sample average & 5.877 & 0.099 \\
& Sample S.D. & 7.107 & 0.272 \\
\hline
\end{tabular}

Source EVENT database. 


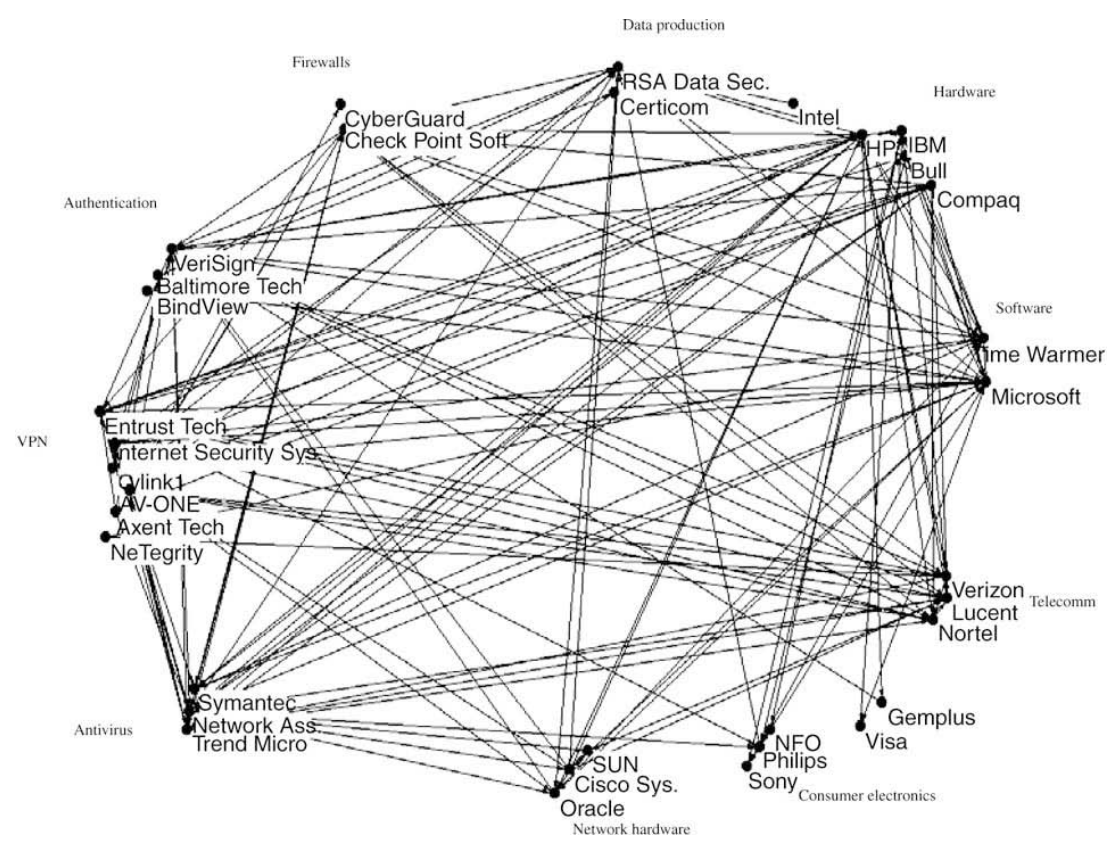

Fig. 4. Network of technological alliances, top ESI start-ups and incumbents by sector specialisation, 1993-1999.

of conducting R\&D projects. The number of different $\mathrm{frms}$ involved is $273 .{ }^{23}$ In Table 8 , the $\mathrm{frms}$ are ranked according to their number of R\&D ventures.

Table 8 shows that the more active frms are the leading start-ups and large ICT frms. This evidence highlights how the fastest growing start-ups used intensively technological alliances during the sample period.

It is worth noticing that only in 43 out of 256 technological alliances partners have the same core niche specialisation. Moreover, taking the sample of 15 top start-ups, in $81 \%$ of cases an alliance with a technological complementary partner was antecedent to the $\mathrm{f} \mathrm{rm}$ product introduction in that specif $\mathrm{c}$ new niche. This evidence is conf rmed by Fig. 4, a network graph on technological alliances among the frms with the highest number of alliances, grouping them according to their initial niche specialisation.

Fig. 4 shows that the 15 top $\mathrm{frms}$ in ESI that enter specialised in a particular niche set up technological linkages with small $\mathrm{frm}$ specialised in other

$\overline{23}$ Note that the partners of an alliance could be more than two. niches of ESI and with large ICT f rms. This seems to conf rm that technological complementarities are important factors at work. The high propensity to conclude alliances among technologically complementary start-ups supports the hypothesis that technological alliances are means to quickly absorb non-core f rm competencies, expanding f rm product variety. And this is beyond the classical alliance benef ts as a type of endorsement (see Stuart et al., 1999). Interviews with managers of some start-ups conf rmed that research consortia and technological co-operations were indispensable to $\mathrm{frm}$ growth and product differentiation. For example, Checkpoint found in 1997 OPSEC a research consortium with the aim of providing users with an integrated Internet security solution. OPSEC is formed now by more than 350 partners, including frms like IBM, Microsoft, Cisco and Siemens. ${ }^{24}$

However, being an important actor in a technological network should be connected with the frm ability to be a strong potential technological partner. Firms that have the high participation intensity in technology

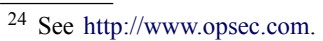


networks have also a sound technological base. Some statistics supports these conjectures: in the EVENT database, among all the frms that set up at least one technological alliance, only $27 \%$ owns a patent in the 380 USPTO class. But this $27 \%$ of $\mathrm{f} \mathrm{rms} \mathrm{accounts} \mathrm{for}$ more than $54 \%$ of technological alliances. External learning is also a function of the in-house effort in R\&D (see for example Cohen and Levinthal, 1989).

\subsubsection{Merger and acquisitions}

During the period 1993-1999, 82 acquisitions have been completed in ESI. In EVENT database we classif ed the frms involved for their active (buyer) or passive (acquired) role. The acquirer $f$ rms are 52 in our sample ${ }^{25}$. The f rms with the highest number of acquisitions are Network Associates (5 acquisitions), Axent Technology (4) and RSA Data Security (4). In Box 4, we brief y analyse the acquisition strategy of these three frms.

The acquisition course of action of these three $\mathrm{f} \mathrm{rms}$ is clearly directed to acquire market shares in new product niches. This trend well represents the strategy in the whole industry. In $77 \%$ of acquisitions partners involved (acquired and buyer) had different product niche specialisation, and in $96 \%$ the acquired $\mathrm{f} \mathrm{rm}$ was less diversify then the buyer. Evidence seems to conf rm that the criterion that led small $\mathrm{frm}$ acquisition strategies was to saturate all the market niches in ESI.

\subsection{Downstream capabilities and geographic expansion}

Investments in co-specialised assets, like service efforts and marketing capabilities are an important mean of appropriation of $R \& D$ returns. Building a sound network of downstream channels and distributors implies a better exploitation of $\mathrm{frm}$ technological resources (Teece, 1986). Also downstream control could lower the rate of possible imitation and act as a barrier to potential entrants. As Teece noted: "A competitive advantage can be gained or lost on the market of complementary assets" (Teece, 1986, p. 289).

\footnotetext{
${ }^{25}$ In most acquisitions the buyer was an ESI start-up, and only in three cases out of 82 , the buyer was an incumbent from other sectors. These data show that the M\&A dynamics were phenomena that occurred inside the groups of start-ups in ESI.
}

Box 4. Mergers and acquisitions in ESI

- In the 1996 Network Associates, which was specialised in the network access design, acquired McAfee, an anti-virus and utility software frms. A year later, it acquired Pretty Good Privacy, one of the leading technological $\mathrm{frms}$ in the data protection area and in 1998 Trusted Information Systems, a Firewall maker.

- RSA Data Security, a data protection specialist, merged in 1996 with Security Dynamics, a f rm operating in the authentication and digital signatures niche. In 1997 RSA acquired Intrusion Detection, a network software security maker, and in 1998 Dynasoft, a f rm specialised in Unix-security networks.

- In 1997, Axent Technology took control of Raptor Systems, one of the most important owner of patents in Firewall technology; in 1998, it acquired Security Network Consulting, a general network design security expert, and in 1999, PassGo Technologies, a storage data protector.

We proxy investments in downstream assets with the number of commercial alliances set up by $\mathrm{frms}$ (as in Gambardella and Torrisi, 1998).

In EVENT database, we registered 296 commercial strategic alliances signed in encryption software sector between 1993 and 1999. These alliances have plain distribution and marketing aims. Table 9 lists the top f rms for number of commercial alliances. It is possible to note that this sample is characterised by top ESI start-ups (Check Point, Axent, etc.) and large ICT f rms (IBM, H\&P, etc.). It is evident that top start-ups are the major investors in downstream assets.

The building of these downstream capabilities is directly linked to a frm's capacity to open new geographic markets where it can establish its presence. The positive outcomes of this dual strategy are several, such as sales and prof $t$ expansion, entry and growth in new product niches, better screening of market opportunities and direct contact with a larger customer base.

The literature has pointed that internationalisation tends to be easier among f rms with high intensity of 
Table 9

Top f rms for number of commercial alliances in ESI, 1993-1999

\begin{tabular}{rlll}
\hline Rank & Firm & $\begin{array}{l}\text { Alliances } \\
(a)\end{array}$ & $\begin{array}{l}a \text { Sales } \\
\text { (US\$ million) }\end{array}$ \\
\hline 1 & Network Ass. & 28 & 0.083 \\
2 & RSA Data Security & 22 & 0.229 \\
3 & Axent Tech. & 14 & 0.402 \\
4 & VeriSign & 13 & 0.128 \\
5 & Computer Ass. & 10 & 0.003 \\
6 & Check Point Soft. & 10 & 0.144 \\
7 & IBM & 10 & 0.000 \\
8 & Time Warner & 9 & 0.003 \\
9 & Secure Computing Corp. & 8 & 0.297 \\
10 & Microsoft & 7 & 0.001 \\
& Sample average & 4.411 & 0.077 \\
& Sample S.D. & 5.194 & 0.185 \\
\hline
\end{tabular}

Source Event database.

$R \& D$ that offer technological complex products with a high level of product differentiation. This holds especially for f rms in which its intangible asset value is large relative to its market value (Ethier, 1986; Markusen, 1995).

Moreover, recent studies (Kotha et al., 2001) have found a positive correlation between intangible assets of software $\mathrm{frms}$ and propensity to internationalise. Other scholars (Morck and Yeung, 1992) found evidence that especially for small, young and dynamic frms the presence of intangible assets is correlated with a high degree of internationalisation and high "abnormal" stock market returns. This is particularly true for niche products with general-purpose functionalities such as the ESI product.

Data show that the main geographic markets for encryption software products are North America and Europe; as a matter of fact, according to Hoovers, in 1999 the $66.7 \%$ of the revenues in ESI came from the US market, followed by Europe (16.1\%) and Asia (3.8\%). Our alliance data show an important tendency to $\mathrm{frm}$ internationalisation. In this respect, we assign to each agreement the country where the alliance investment is direct. We then calculated for each $\mathrm{f} \mathrm{rms}$, the Herf ndahl index on the commercial alliances by year and by country. As Fig. 5 shows, when the number of commercial alliances is rising, the dispersion of alliances among different countries increases. Firms in ESI use commercial agreements also to open new geographical markets. This was extremely important for $\mathrm{frms}$ in emerging countries like Israel (Aladdin, CheckPoint) or Ireland (Baltimore) where the dimension of indigenous markets was small (Arora et al., 2001). Managers at Baltimore and Checkpoint agree in stressing the importance of $\mathrm{f} \mathrm{rm}$ internationalisation strategies: "It was strategically prof table in the long run that we do not focus on our local customers from the beginnings".

In order to summarise this section, we have seen that product differentiation was central for start-ups in order to gain competitive advantages when scale

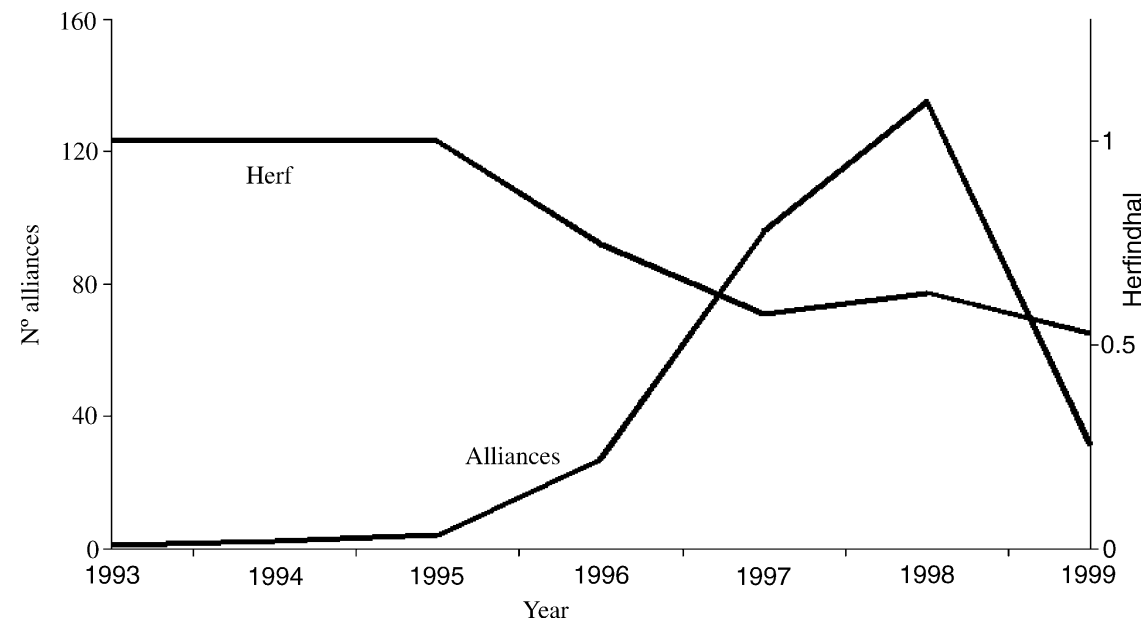

Fig. 5. Firm number of commercial alliances compared to their geographic expansion (Herf ndahl Index). 
economies are small. Moreover, investments in co-specialised assets, especially aimed to the f rm geographic expansion, are necessary to sustain growth of young frms. At this regards, alliances appear as good tools to study small $\mathrm{frm}$ behaviour.

\section{Conclusions}

In this paper, we analysed the birth of a new market niche in the software industry. We depicted the different phases of competition and the strategic responses of main actors, focusing on the process of entry by start-ups and post-entry $f \mathrm{rm}$ strategies.

We have shown that a sound technological base, a broad product variety and structured co-specialised assets are variables strongly correlated to start-up probability to survive and grow.

In detail, we illustrated the strict link between innovation and new frm formation, where innovation was the key to open new market niches, avoiding entry barriers and discovering new potential customers. Following this point, entrepreneur characteristics were fundamental to understand start-up performance especially during its frst years. ESI in fact was a classical case study where inventors become entrepreneurs exploiting their technological knowledge.

We then stressed the importance of patents as a tool to defend $\mathrm{frm}$ knowledge assets. This is quite unusual in the software industry, where frms do not extensively protect their innovation by means of patents. But in ESI, patents helped to build a market for technology that was essential in shaping competitive outcomes. This is also highlighted by the presence of two separated markets for software products and mathematical algorithms.

We saw that if technology was crucial in determining the positive result of $\mathrm{frm}$ entry, exploitation of economies of scope direct to product differentiation and investments in downstream assets linked with $\mathrm{f} \mathrm{rm}$ geographic expansion represented the key to understand frm growth when scale economies are small. At this regards, alliances appear as essential tools to achieve these results for small $\mathrm{frms}$ that usually rely on scarce resources.

Sound evidence conf rmed the importance of small $\mathrm{f}$ rms in opening new markets where large incumbents, for several reasons, have low incentives to invest. On the other side, we highlighted how large established f rms acted as incubators of technological competencies embedded in the future entrepreneurs, and also as important actors both in the technological and commercial networks in ESI.

This paper leaves some points of discussion open. The relationship between f rm initial capabilities and the patterns of $\mathrm{f} \mathrm{rm}$ growth is still in need to be deeper studied.

In ESI, the coexistence of good initial capabilities and optimal growth strategies determinate the success of a start-up. But causes and consequences of a f rm's success do still not have a clear-cut role. In future works it will be interesting to investigate if: (i) initial $\mathrm{f} \mathrm{rm}$ competencies embedded in entrepreneurs; and (ii) frm strategies direct towards product differentiation and geographical expansion are the two faces of the same mechanism, or, otherwise, whether $\mathrm{f} r \mathrm{rm}$ strategies produce an effect beyond $\mathrm{frm}$-founder initial capabilities.

\section{Acknowledgements}

I am grateful for assistance and discussions to Ashish Arora, Giovanni Dosi, Andrea Fosfuri, Alfonso Gambardella, Bronwyn Hall, Steven Klepper, Alessandra Luzzi, Keith Pavitt and Salvatore Torrisi. We also thank managers at Checkpoint, Baltimore, Aladdin and Network Associates for the interviews. The paper was greatly improved by the suggestions of Giulio Bottazzi, Paola Giuri, Giorgio Fagiolo in the frst stages of work.

\section{References}

Anand, B.N., Khanna, T., 2000. Do f rms learn to create value? The case of alliances. Strategic Management Journal 21 (3), 295-315.

Arora A., Gambardella A., Torrisi S., 2001. In: The Footsteps of Silicon Valley? Indian and Irish Software in the International Division of Labour, SIEPR Policy paper no. 00-41.

Audretsch, D., 1991. New-frm survival and the technological regime. Review of Economics and Statistics 73 (3), 441450.

Baron, J.N., Hanna, M.T., 2002. Organizational blueprints for success in high-tech start-ups. California Management Review 44 (3), 8-36.

Baum, J.A.C., Calabrese, T., Silverman, B.S., 2000. Don't go it alone: alliance network composition and start-ups' performance 
in Canadian biotechnology. Strategic Management Journal 21, 267-294.

Bessen J., Hunt R.H., 2003. An empirical look to software patents, Paper presented at the EPIP Conference, Munich, April 2003.

Bhide, A., 2000. The Origin and Evolution of New Businesses, Oxford University Press.

Blanchower, D., Oswald, A., 1998. What makes an Entrepreneur? Journal of Labor Economics 16 (1), 26-60.

Bresnahan, T., Trajtenberg, M., 1995. General purpose technologies engines of growth? Journal of Econometrics 65 (3), 83108.

Chrisman, J., Bauerschmidt, A., Hofer, C., 1998. The determinants of new venture performance: an extended model. Entrepreneurship: Theory and Practice 23 (1), 5-7.

Churchill, N., Lewis, V., 1983. The Five Stages of Small Business Growth. Harvard Business Review, May, 30-50.

Cohen, W., Levinthal, D., 1989. Innovation and learning: the two faces of R\&D. Economic Journal 99 (397), 569-596.

Cohen, W., Nelson, R., Walsh, J., 2000. Protecting their Intellectual Assets: Appropriability Conditions and Why US Manufacturing Firms Patent (or not), NBER, WP 7552.

Dodge, H., Fullerton, S., Robbins, J., 1994. Stage of the organizational life cycle and competition as mediators of problem perception for small businesses. Strategic Management Journal 15 (2), 121-134.

Dunne, T., Roberts, M., Samuelson, L., 1988. Patterns of frms entry and exit in US manufacturing industries. Rand Journal of Economics 19 (2), 495-515.

Ethier, W., 1986. The multinational f rm. Quarterly Journal of Economics 101 (4), 805-834.

Gambardella, A., Torrisi, S , 1998. Do technological convergence implies convergence in markets? Evidence from the Electronics Industry, Research Policy 27 (5), 445-463.

Gartner, W., 1985. A conceptual framework for describing the phenomenon of new venture creation. Academy of Management Review 10 (4), 696-706.

Geroski, P., 1995. What do we know about entry? International Journal of Industrial Organization 13 (4), 421-440.

Gosnell, G., 1999. Internet related intellectual property issues. Journal of Internet Law 2 (4), 23-34.

Hanks, S., Chandler, G., 1994. Patterns of functional specialisation in emerging high-tech frms. Journal of Small Business Management 32 (2), 23-37.

Henderson, R., 1993. Underinvestment and incompetence as responses to radical innovation - evidence from the photolithographic alignment equipment industry. Rand Journal of Economics 24 (2), 248-270.

Hippel von, E., 1988. The Sources of Innovations, Oxford University Press, NY.

Holmes, T., Schmitz, J., 1990. A theory of entrepreneurship and its application to the study of business transfers. Journal of Political Economy 98 (2), 265-294.

Kazanjian, R., 1988. Relation of dominant problems to stages of growth in technology-based new ventures. Academy of Management Journal 31 (2), 257-279.
Kazanjian, R., Rao, H., 1999. The creation of capabilities in new ventures: a longitudinal study. Organization Studies 20 (1), 125-137.

Kekre, S., Srinivasan, K., 1990. Broader product line: a necessity to achieve success. Management Science 36 (10), 12161231.

Kiefer, N.M., 1988. Economic duration data and hazard functions. Journal of Economic Literature 26 (2), 646-679.

Klepper, S., 1996. Entry, exit, growth and innovation over the product life cycle. American Economic Review 86 (3), 562584.

Klepper, S., Sleeper, S., 2000. Entry by Spin-off, Working Paper, Carnegie Mellon University.

Klepper, S., 2001. Employee start-ups in high-tech industries. Industrial and Corporate Change 10 (3), 639-674.

Kotabe, M., Swan, K., 1995. The role of strategic alliances in hightechnology new product development. Strategic Management Journal 16 (8), 621-636.

Kotha, S., Rindova, V., Rothaermel, F., 2001. Assets and actions: $\mathrm{frm}$-specif $\mathrm{c}$ factors in the internationalization of US internet f rms. Journal of International Business Studies 32 (4), 769792.

Lancaster, K., 1990. The economics of product variety. Marketing Science 9 (3), 189-211.

Markusen, J., 1995. The boundaries of multinational enterprises and the theory of international trade. Journal of Economic Perspectives 9 (2), 169-189.

Meyer, M., Roberts, E., 1986. New product strategy in small technological-based frms: a pilot study. Management Science 32 (7), 806-821.

Mitra, R., Pingali, V., 1999. Analysis of growth stages in small f rms: a case study of automobile ancillaries in India. Journal of Small Business Studies 37 (3), 62-71.

Morck, R., Yeung, B., 1992. Internationalization: an event study test. Journal of International Economics 33 (1), 41-56.

Olson, P., 1987. Entrepreneurship and management. Journal of Small Business Management 25 (3), 7-14.

Pavitt, K., 1988. International patterns of technological accumulation. In: Hood, N., Vahlne, J. (Eds.), Strategies in Global Competition. Groom Helm, pp. 123-143.

Riccaboni, M., Pammolli, F., 2001. On f rm growth in networks. Research Policy 31 (8), 1405-1416.

Sakakibara, M., 1997. Heterogenity of f rm capabilities and cooperative research and development: an empirical examination of motives. Strategic Management Journal 18 (4), 143164.

Shane, S., 2001. Technological regimes and new $\mathrm{f} \mathrm{rm}$ formation. Management Science 47 (9), 1173-1190.

Shane, S., Venkataraman, S., 2000. The promise of entrepreneurship as a feld of research. Academy of Management Review 25 (1), 217-226.

Smith, R., 1999. Internet Cryptography, Addison-Wesley, Reading, USA.

Soreson, O., 2000. Letting the market work for you: an evolutionary perspective on product strategy. Strategic Management Journal 21 (5), 577-592. 
Stuart, T.E., Hoang, H., Hybels, R.C., 1999. Interorganizational endorsements and the performance of entrepreneurial ventures. Administrative Science Quarterly 44 (2), 315-349.

Teece, D., 1986. Prof ting from technological innovation: implications for integration, licensing and public policy. Research Policy 15 (1), 285-305.

Terpstra, D., Olson, P., 1993. Entrepreneurial start-up and growth: a classif cation of problems. Entrepreneurship: Theory and Practice 17 (3), 5-21.

Torrisi, S., 1998. Industrial Organisation and Innovation: an International Study of the Software Industry, Edward Elgar Publ., Cheltenham, UK.
Vinnell, R., Hamilton, R., 1999. A historical perspective on small $\mathrm{f} \mathrm{rm}$ development. Entrepreneurship: Theory and Practice 23 (4), 5-12.

Wagner, J., 1994. The post-entry performance of new small f rms in German manufacturing industries. Journal of Industrial Economics 42 (2), 141-154.

Zacharakis, A., Meyer, G., DeCastro, J., 1999. Differing perceptions of new venture failure: a matched exploratory study of venture capitalists and entrepreneurs. Journal of Small Business Management 37 (3), 1-10. 